\title{
Hintainformaation välittyminen ja keskittyneen vähittäiskaupan aiheuttama epäsymmetrisyys Suomen lihamarkkinoilla
}

\author{
Kati Jalonoja ja Kyösti Pietola \\ MTT Taloustutkimus, Luutnantintie 13,00410 Helsinki,kati.jalonoja@mtt.fi, kyosti.pietola@mtt.fi
}

\begin{abstract}
Johdanto
EU:n yhteisen maatalouspolitiikan tavoitteena on saavuttaa alueellisesti yhdentyneet elintarvikemarkkinat Euroopassa. Alueellisesti yhdentyneillä markkinoilla hintainformaatio välittyy tehokkaasti jäsenmaiden välillä. Komissio painottaa, että myös jäsenmaiden harjoittaman kansallisen politiikan ja säädösten tulisi tukea päämäärää tiedonkulultaan tehokkaasta, yhteisestä eurooppalaisesta markkina-alueesta. Suomi edustaa EU -markkina-alueella pientä ja kaukaista osa-aluetta. Markkinayhdentymisen aste vaikuttaa Suomessa kansallisiin maataloustukiin, jotka täydentävät EU:n yhteistä maatalouspolitiikkaa. Yhdentymisen aste vaikuttaa myös kilpailunrajoituslain määrittämiiin toimenpiteisiin, jotka säätelevät kansallisen elintarviketeollisuuden rakennetta. Näillä molemmilla on vaikutusta kotimaisen elintarvikesektorin kilpailukykyyn ja täten kotimaisten elintarvikkeiden tarjonnan vahvuuteen EU-markkinoilla.

Useimmissa Euroopan maissa elintarvikkeiden vähittäiskauppa on keskittynyttä. Keskittyneintä se on Suomessa, missä 90-luvun puolivälissä viiden suurimman vähittäiskaupan osuus kokonaismarkkinoista oli 96\%. Alhaisinta keskittyminen on Italiassa. Keskittynyt markkinarakenne on avaintekijänä yritysten oligopolistiseen käyttäytymiseen. Oligopolistisilla markkinoilla yritykset eivät kilpaile hinnoilla. Ostajaosapuoli saattaa käyttää myös tuonninuhkaa kaupan ehdoista sovittaessa. Tämä johtaa hyvinvointitappioihin niin yksittäisen kuluttajan kuin koko yhteiskunnankin kannalta. Suomen lihamarkkinoiden yhtenä ongelmana onkin se, että vähittäiskauppa on tuotantosektoria keskittyneempää. Vaikka kotimaisia lihantarjoajiakin on vain muutama ja ne ovat kansallisessa mittakaavassa suuria toimijoita, ovat ne kuitenkin Euroopan mittakaavassa, ja maailmanlaajuisesti, pieniä toimijoita.

Tämän tutkimuksen tavoitteena on lisätä tietoa kotimaisista lihamarkkinoista ja markkinaosapuolten kilpailuasemasta sekä edesauttaa markkinoiden toimivuutta. Tutkimuksessa selvitetään, onko Suomen lihamarkkinoilla viitteitä oligopolistisesta käyttäytymisestä, kuten strategisesta hintasignaloinnista, joka oleellisesti heikentää markkinoiden tehokkuutta.

Tutkimuksessa estimoidaan ja testataan tilastollisesti aikasarjaekonometrian menetelmin se, kuinka tehokkaasti hintainformaatio välittyy Euroopan markkinoilta Suomeen. Viitteet oligopolistisesta käyttäytymisestä testataan epäsymmetrisellä virheenkorjausmallilla. Estimaattorien tehokkuutta parannetaan ottamalla huomioon mahdolliset liiketoimikustannukset. Liiketoimikustannusten vuoksi vaaditaan tiettyä kynnysarvoa suurempi hintamuutos ennen kuin hintamuutos välittyy markkinapaikalta toiselle (esim. BenKaabia, Gil \& Boshnajaku (2002); Meyer \& von Cramon-Taubadel (2002)).
\end{abstract}

\begin{abstract}
Aineisto
Tutkimusaineistona käytetään suomalaisia ja saksalaisia sianlihan ja naudanlihan hintoja. Hintahavainnot ovat viikoittaisia. Tarkasteltavat suomalaiset sianlihan ja naudanlihan hinnat ovat tuottajalle maksettuja hintoja yhdestä teurastetusta lihakilosta teurastamon portilla (hinta ei sisällä kuljetuskustannuksia teurastamolle). Saksalaiset sianlihan hinnat ovat markkinahintoja Hampurissa. Saksalaiset naudanlihan hinnat taas ovat markkinahintoja Baijerin vapaavaltiossa. Tutkimusaineisto kattaa Suomen EU-jäsenyysvuodet eli ajanjakson tammikuusta 1995 joulukuuhun 2003.
\end{abstract}

\section{Ekonometrinen malli}

Aluksi suomalaisen ja saksalaisen lihan hinnan logaritmimuunnosta $\left(\ln \mathrm{p}_{\mathrm{t}+1}\right)$ selitetään autoregressiomallilla AR(k), jossa viipeiden lukumäärä on $\mathrm{k}$. Kummankin maan sianlihan ja naudanlihan hintaa tarkastellaan erikseen. Yhtälöön lisätään myös kausivaihtelua mittaava polynomifunktio. Näin päädytään malliin:

(1) $\ln p_{t+1}=\phi_{0}+\sum_{i=0}^{k} \phi_{1+i} \ln p_{t-i}+S(t)+\varepsilon_{t+1}$ 
missä $\phi$ ovat parametreja ja $\varepsilon_{t+1}$ on virhetermi.

Hintasarjaa kuvaavan mallin tilastolliset ominaisuudet riippuvat ratkaisevasti siitä, onko sarja stationaarinen vai ei. Kuitenkin stationaarisuustestien voima on heikko etenkin, jos sarjassa epäillään olevan rakenteellinen muutos (Leybourne and Newbold 2000). Tämän vuoksi stationaarisuustesteissä käytetään nollahypoteesina sekä epästationaarista yksikköjuuriprosessia että stationaarista prosessia (Dickey ja Fuller 1979, Kwiatkowski ym. 1992).

Jos hintasarjojen havaitaan olevan epästationaarisia, testataan suomalaisten ja saksalaisten hintasarjojen välinen yhteisintegroituvuus erikseen sianlihan ja naudanlihan hinnoille. Mikäli sarjat ovat yhteisintegroituneet, niiden välille voidaan löytää lineaarinen kombinaatio, joka on stationaarinen. Yhteisintegroituvuusyhtälöstä voidaan estimoida pitkän aikavälin joustot. Lopuksi voidaan virheenkorjausmallista estimoida lyhyen aikavälin joustot ja sopeutumisen nopeus.

Virheenkorjausmallissa suomalaisen lihan hintamuutosta $\left(\Delta \mathrm{p}^{\mathrm{FIN}}\right)$ selitetään saksalaisen lihan hintamuutoksella $\left(\Delta \mathrm{p}^{\text {GER }}\right)$, virheenkorjaustermillä (ECT) ja kausivaihtelua mittaavalla polynomifunktiolla $S(t)$. Näin päädytään malliin:

(2) $\Delta \ln p_{t}^{F I N}=\alpha_{0}+\alpha_{1} \Delta p_{t}^{G E R}+\alpha_{2} E C T_{t-1}+\alpha_{3} \Delta p_{t-1}^{F I N}+\alpha_{4} \Delta p_{t-1}^{G E R}+S(t)+\varepsilon_{t}$,

missä pitkän aikavälin vaikutus hallitaan virheenkorjaustermin $E C T_{t-1}=\ln p_{t-1}^{F I N}-k \ln p_{t-1}^{G E R}$ avulla. Virheenkorjaustermi kuvaa tasapainoa hetkellä t-1 ja on siksi stationaarinen I( $(0)$-prosessi. Parametrit $\alpha_{1}$, $\alpha_{3}$ ja $\alpha_{4}$ ilmaisevat lyhyen aikavälin joustot, kun taas $\alpha_{2}$ osoittaa nopeuden, jolla pitkän aikavälin tasapainoon sopeudutaan.

Virheenkorjaustermin symmetrisyyttä testataan yhtälöllä

(3) $\Delta \ln p_{t}^{F I N}=\alpha_{0}+\alpha_{1} \Delta p_{t}^{G E R}+\alpha_{2} E C T_{t-1}+\alpha_{3} E C T_{t-1}^{-}+\alpha_{4} \Delta p_{t-1}^{F I N}+\alpha_{5} \Delta p_{t-1}^{G E R}+S(t)+\varepsilon_{t}$

Virheenkorjausmallia yleistetään vielä kynnysarvoja käyttävään virheenkorjausmalliin, jossa hinta sopeutuu pitkän aikavälin tasapainoon vain jos nykyinen hinta on riittävän alhaalla tai korkealla verrattuna tasapainohintaan. Estimoitava malli on tällöin muotoa

$\Delta \ln p_{t}^{F I N}=\phi_{0}+\beta_{0} \Delta \ln p_{t}^{G E R}+\beta_{1} \Delta^{-} \ln p_{t}^{G E R}+\varphi_{1} E C T_{t-1}+\varphi_{2} D^{-} E C T_{t-1}+\varphi_{3} D^{+} E C T_{t-1}$ $+S(t)+\beta_{2} \Delta \ln p_{t-1}^{F I N}+\beta_{3} \Delta \ln p_{t-1}^{G E R}+\beta_{4} \Delta^{-} \ln p_{t-1}^{G E R}+\varepsilon_{t}$

missä $\mathrm{D}^{-}=1$ if $E C T_{t-1}<c_{1}<0$, muulloin $\mathrm{D}^{-}$on nolla. Yhtäläisesti, $\mathrm{D}^{+}=1$ jos $E C T_{t-1}>c_{2}>0$, muulloin $\mathrm{D}^{+}$on nolla. Malli estimoidaan ehdollisesti eksogeenisesti annetuilla kynnysarvoilla $\mathrm{c}_{1}$ ja $\mathrm{c}_{2}$, jotka on mallitettu polynomifunktioilla.

\section{Tulokset}

Tutkimuksesta ei ole vielä saatu tuloksia. Tutkimuksessa tullaan saamaan kvantitatiivisia estimaatteja sisäisten ja ulkoisten tarjonta- ja kysyntäshokkien vaikutuksista suomalaisilla lihamarkkinoilla. Kun tiedetään, onko markkinaepävarmuus lihamarkkinoiden sisäisten vai ulkoisten shokkien seurausta, voidaan arvioida sitä, mikä on keskittyneen vähittäiskaupan rooli hintashokkien välittymisessä. Tämän avulla voidaan tehdä päätelmiä siitä, onko suomalaisilla lihamarkkinoilla epäsymmetrisyyttä, joka johtuu oligopolistisesta käyttäytymistä. Tutkimustulosten avulla voidaan arvioida kotimaisen lihasektorin markkina-asemaa suhteessa vähittäiskaupan ostajaryhmittymiin. Samalla saadaan myös tietoa harjoitetun politiikan vaikuttavuudesta lihasektorin sopeutumisessa entistä kilpaillummille markkinoille. Tulokset hyödyttävät koko lihaketjua. 


\section{Kirjallisuus}

Ben-Kaabia, M., Gil, José M. \& Boshnjaku, L. 2002. Price transmission asymmetries in the Spanish lamb sector. Paper presented in the 10th EAAE-Congress in Zaragoza in August 2002. Available in CD-rom: Exploring Diversity in the European Agri-Food System. X Congress, European Association of Agricultural Economists (EAAE). Programme. Zaragoza, Spain, 28-31 August 2002. Available in Internet: http://www.eaae.org/activities/indexa.htm Dickey, D. A. and Fuller, W. A. 1979. Distribution of estimates for autoregressive time series with unit root. Journal of American Statistical Association 74: 427-431.

Kwiatkowski, D., Phillips, P., Schmidt, P. \& Shin, Y. 1992. Testing the null hypothesis of stationarity against the alternative of a unit root. Journal of Econometrics 54: 159-178.

Leybourne, S.J. \& Newbold, P. 2000. Behavior of Dickey-Fuller t-tests when there is a break under the alternative hypothesis. Econometric Theory 16: 779-789.

Meyer, J. \& von Cramon-Taubadel, S. 2002. Asymmetric Price Transmission: A Survey. Paper presented in the 10th EAAE-Congress in Zaragoza in August 2002. Available in CD-rom: Exploring Diversity in the European Agri-Food System. X Congress, European Association of Agricultural Economists (EAAE). Programme. Zaragoza, Spain, 28-31 August 2002. Available in Internet: http://www.eaae.org/activities/indexa.htm 